\title{
Research on Export Trade of Agricultural Products in Jilin Province under CAFTA Framework
}

\author{
Fang Wang \\ Jilin Engineering Normal University, Changchun Jilin, 130011, China
}

\begin{abstract}
Key words: CAFTA, Export trade of agricultural products in Jilin Province, ASEAN Free Trade Area, competitiveness, Development countermeasure.
\end{abstract}

\begin{abstract}
When China established the idea on future development framework of "One Belt and One Road” (OBOR), it was proposed that Jilin Province, as a great province of agriculture in the northeast, should establish an effective regional cooperation platform, give play to its advantages in agricultural development, accelerate multi-cooperation with ASEAN countries in the field of export trade of agricultural products and establish a relationship of political trust and economic integration fully based on the existing bilateral multi-mechanism relationship with relevant ASEAN countries under the overall background of CAFTA. Therefore, this paper uses export trade of agricultural products in Jilin Province as the theme, analyzes the actual status and competitive performance of agricultural products in Jilin Province specific to export trade for ASEAN based on diamond model and finally puts forward development countermeasures of Jilin Province in this field in the future.
\end{abstract}

\section{Introduction}

China and ten countries of ASEAN officially signed "China and ASEAN Trade Area" (CAFTA) Agreement in November 2002, which established a bridge for expanding their economy and trade exchange and promoting cooperation dialogue and trade and investment of enterprises in multiple countries. As China is the free trade area with the largest population in the world, its multiple cities shall undertake the responsibility of economy and trade exchange with ASEAN, accelerate the cooperation with ASEAN countries in three main industries, optimize export structure and improve bilateral trade mechanism.

\section{Relevant discussions on agricultural product trade under CAFTA framework}

The main cooperation framework of CAFTA is China-ASEAN Comprehensive Economic Cooperation Framework Agreement. Service Trade Agreement, Goods Trade Agreement and Dispute Settlement Mechanism Agreement issued subsequently serve and provide legal protection around it. In various agreements signed and implemented, regulations on agricultural product trade mainly involve three aspects: first, tariff reduction of agricultural product trade between China and ASEAN. Currently, China and ten countries of ASEAN have reached an agreement on rapid tariff reduction for the export of over 560 kinds of agricultural products. The objective of zero tariff of agricultural products has been achieved for Singapore, Malaysia, Thailand and Philippines etc. in 2006. Appropriate protection has been provided for tariff reduction for other cooperating countries according to their basic national conditions. Therefore, the aim of CAFTA is to gradually reduce tariff and provide appropriate protection in this aspect.

In terms of quantitative limitation and quarantine of animals and plants, it is expected to break through technical barriers to trade early, adhere to principles, establish agricultural product import and export trade process conforming to legal regulations of both parties and solve and avoid some sensitive problems according to relevant articles of WTO to avoid unnecessary trade friction.

Finally, with respect to the remedy of agricultural product export trade, CAFTA proposes to put forward supporting measures for relevant agricultural product export trade. If the import quantity of agricultural products of a country increases and seriously harms and threatens its domestic industry, it 
is required to implement relevant supporting measures. For example, subsidy and anti-subsidy should be operated in strict accordance with relevant international clauses of WTO.

Since the signing of CAFTA Agreement, the scale of bilateral trade between China and ASEAN shows a trend of progressive increase year by year. The total trade volume of agricultural product import has jumped to 41.257 billion US dollars in 2016 from 6.025 billion US dollars at the beginning of implementation of relevant agreement in 2002. Its amount of increase is about 7 times. In 2015, the amount of export of Chinese agricultural products to various countries of ASEAN reached 8.323 billion US dollars. All this makes China become the first largest trade partner country of ASEAN. It's worth noting that Jilin Province has made undeniable contributions in agricultural product export trade of China. Its trade volume of export to various countries of ASEAN has always been kept between $15.45 \%$ and $18.83 \%$ over the past decade. It is a stable power of contributions to agricultural product export trade of China under CAFTA framework ${ }^{[1]}$.

\section{Development status of export trade of agricultural products in Jilin Province under CAFTA framework}

\section{Basic development status of export trade of agricultural products}

As a great province of agriculture, Jilin has been committed to developing export-oriented agriculture over the years. Under CAFTA framework, Jilin Province is always the largest trade partner of agricultural product import of ASEAN. The total volume of bilateral trade reached 1.481 billion US dollars in 2015. The amount of export of Jilin Province to various countries of ASEAN has jumped to 1.295 billion US dollars in 2015 from 0.132 billion US dollars in 2002. The annual average rate of increase reaches $61.8 \%$.Jilin has been endeavoring to develop bilateral trade of agricultural products with overseas countries, positively respond to national policies and optimize its bilateral trade mode of agriculture in the past decade.

\section{Entrepreneurial mode of agricultural product export trade of Jilin}

Jilin has greatly developed entrepreneurial mode of agricultural product export in recent years. There are two main modes which have driven the rapid development of regional foreign agriculture and promoted the bilateral trade relationship between Jilin and ASEAN countries.

First, export mode. Let's take Haoyue Group which is famous in Jilin for example. Since the establishment of Free Trade Area between China and ASEAN in 2010, it has started strong entrepreneurial activities of export trade to Southeast Asia region and made great achievements. Haoyue Group has realized bilateral cooperation with some agents in various countries of ASEAN, exported a lot of agricultural products such as cow and sheep to foreign countries, successfully got involved in the market of various countries of ASEAN and occupied large shares of the local market. The market share of Haoyue in Vietnam is up to $85 \%$, which drives the development of bilateral trade relationship of Jilin and ASEAN in export and import. Such export mode has gradually formed the main sign of agricultural product export trade of Jilin Province.

Second, contract mode. Jilin Province is the most important commercial grain production base in China as well as the homeland of corn and soybean. The planting of various food products including sorghum, rice, wheat and tuber also improves the international status of Jilin in CAFTA agricultural field. In terms of trade operation type, contract mode of agricultural product export trade of Jilin Province is mainly based on license operation and technical protocol. Such contract mode is rarely adopted in other provinces. 


\section{Analysis on competitiveness of Jilin-ASEAN agricultural product export trade under the theory of diamond model}

Michael Porter diamond Model comes from Porter diamond theory, which advocates national competitive advantage theory and is an expressive theory stating competitiveness. The theory was put forward by Michael Porter, a famous strategic managerialist in Harvard Business School in USA, in 1990. Its main function is to analyze how can a country form overall advantages in an industry and develop strong competitiveness internationally. Porter considered in the research process that production factors, demand conditions, industrial support performance, enterprise strategy and the performance of competitors are required to see whether relevant industry of a country has the potential of international competition. In his opinion, these four factors have bidirectional effect and just form a typical diamond system. Government and market opportunity also play a decisive role in four factors of diamond theory.

Based on basic viewpoints clarified by Porter diamond model, the possibility whether Jilin Province can influence various countries of ASEAN under CAFTA framework to the greatest extent in agricultural product export trade should be analyzed specifically based on four factors above. With respect to production factors, Jilin Province has distinctive agricultural advantages. Its climatic conditions, species, number of labor force and area of agricultural land rank top in China. This belongs to internal fundamental strength not requiring unnecessary details. This paper mainly considers several other aspects.

\section{Agricultural demand conditions}

Jilin has a large scale of market demands of agricultural products. The rate of increase of provincial GDP is over $12.9 \%$ on average annually. However, its urbanization rate is low, which is only $43.1 \%$. This hinders the improvement of economic development level of Jilin to a certain extent and indirectly causes the low level of demand nature of agricultural products in the province. However, with the establishment of ASEAN Free Trade Area and constant expansion of the scale of agricultural product export trade cooperation between Jilin and ASEAN, diversified demands of overseas countries for exported agricultural product species of Jilin also guide agricultural consumption of Jilin Province. This impels agricultural products of Jilin to constantly expand resource and species advantages. Agricultural demand conditions tend towards high-end international level.

\section{Performance of supporting industry related to agriculture}

Agricultural industry of Jilin has a high agglomeration degree. It has much to offer with respect to the development of staple products and rare and precious products in agricultural development. In particular, the participation of deep processing field of agricultural products promotes the rapid development of emerging agricultural industrialization in the whole province and becomes a bright spot of agricultural export trade system of Jilin Province. In addition, Jilin Province has added such projects as leisure agricultural operation and agricultural machinery export operation etc. in the link of export trade towards ten countries of ASEAN since 2012.The addition of these projects has directly increased export trade income of agricultural products of Jilin by $24.7 \%$ and realized an annual profit of 2.035 billion Yuan. With the establishment of multiple new agricultural standardization demonstration areas (42), the establishment of relevant industrial system based on agricultural support tends to be mature and improved gradually.

\section{Enterprise strategy and performance of competitors}

Agricultural product market of Jilin has strong main competitiveness. The rate of its agricultural product processing and conversion and appreciation is always high. In recent years, it has been creating its own agricultural product brand with an expectation to expand export trade and consolidate its position in ASEAN Free Trade Area. In terms of enterprise strategy, production enterprises of agricultural products in Jilin are improving their technological content, expanding their scale and extending affiliated ecological chain of the industry in succession. Other provinces in the 
northeast such as Heilongjiang and Liaoning have their respective unique advantages in the brand of exported agricultural products. However, Jilin has obvious advantages in bilateral trade of agricultural products with ASEAN countries.

\section{Government aspect}

In order to promote multilateral exchange of its agriculture with ASEAN Free Trade Area, the government of Jilin has issued relevant policies in production, processing and import and export and given preferential subsidies and supporting services to agricultural enterprises and individual farmers to a great extent. The support of the government has greatly encouraged the export of agricultural products of Jilin to various countries of ASEAN. In 2012, Jilin issued the policy of "reward for great counties of live pigs" and provided subsidies for fine breed of livestock and animal epidemic prevention. These measures have undoubtedly promoted the increase of grain yield and farmers' income in Jilin to a great extent. In addition, the State Council published Opinions on Supporting Development of Leading Enterprises of Agricultural Industrialization in 2012, expecting to encourage leading agricultural enterprises of Jilin to greatly develop the production of agricultural products and accelerate the development of bilateral cooperative relationship of import and export between Jilin and ASEAN countries. The establishment of Development Planning of Agricultural Product Processing Industry in Jilin has given certain financial, tax and credit preferential benefit support to the operation of agricultural industry in the province. In 2014, "Conference of Featured Agricultural Product Enterprises in Jilin Entering ASEAN" was held in Bangkok, Thailand, which aimed at promoting bilateral trade between Jilin and various ASEAN countries and especially expecting agricultural enterprises of Jilin to go out bravely with featured agricultural products and create significant opportunities for agriculture of Jilin ${ }^{[2]}$.

\section{Optimized development countermeasures of export trade of agricultural products in Jilin Province under CAFTA framework}

Under the framework of CAFTA China-ASEAN Free Trade Area, agricultural product export trade of Jilin should continue to take the path of industry optimization, give play to its advantages of agricultural production and optimize development countermeasures of export trade from agricultural product export structure, the transformation of production mode with scientific research intensity and response to non-tariff barriers of ASEAN.

\section{Agricultural product export structure}

To increase the export proportion of agricultural products with high additional value towards various ASEAN countries, the main practice of Jilin is to improve the degree of agricultural product processing. This is an important standard for measuring the level of economic development of a region. Deep processing enterprises of meat like Haoyue are the model of CAFTA foreign trade in Jilin. Therefore, local government of Jilin should positively encourage other large agricultural product processing enterprises to expand the scale of deep processing of agricultural products, conduct agricultural product processing and reformation with Chinese characteristics and transform production mode. For example, for countries with high per-capita consumption level and poor agricultural resources like Brunei and Singapore, it is required to enhance the export trade of primary agricultural products, focus on the complement of lacking agricultural product resources and meanwhile stand on the principle of high quality and low cost. For countries like Philippines, Indonesia and Malaysia, it is required to emphasize advantages of transportation cost, export good economic crops, fruit and vegetables, complement each other's advantages through bilateral trade relationship of agricultural products and drive the development of export trade of primary agricultural products. 


\section{Transformation through scientific research strength}

In terms of agricultural production mode and additional value of products, Jilin has certain advantages. However, it has a long way to go in terms of agricultural scientific research and power input. Therefore, it is required to strengthen its cooperation and exchange with ASEAN in agricultural technology and introduce excellent crop planting, freshwater aquaculture and livestock feed technologies. Jilin can make an appointment with various ASEAN countries to hold various agricultural scientific and technological seminars, conduct agricultural technological exchange and study and strengthen the cooperation with ASEAN in export trade at both technical and emotional levels. As Changchun, Jilin holds Northeast Asia Agricultural Expo annually, it is recommended to hold ASEAN and Southeast Asia Agricultural Expo to promote agricultural economic communication and joint progress with ten countries of ASEAN.

\section{Non-tariff barriers of ASEAN}

It is required to strictly perform SPS agreement (Agreement on Sanitary and Plant Sanitary Measures in the process of agricultural export trade contact with ASEAN countries, gradually eliminate non-tariff barriers through SPS agreement and influence the export of agricultural products under the principle of protecting the health of human beings, animals and plants. In other words, Jilin and ASEAN countries should constantly strengthen the examination of epidemic situation of animals and plants and the safety of agricultural products, eliminate food safety problems and conduct public health security work well while maintaining steady growth trend of bilateral trade volume. Meanwhile, it is also required to strengthen SPS cooperation and exchange with ASEAN countries, improve relevant laws and regulations, draw lessons from SPS successful experience of some ASEAN countries selectively and pull sustainable growth of export trade economy of Jilin ${ }^{[3]}$.

Conclusion: Jilin has natural geographic advantages, which is also the reason why it can greatly develop agricultural product export trade with ASEAN under CAFTA framework. With the formal launching of China-ASEAN Free Trade Area in 2010, CAFTA has entered the era of "zero tariff”. Jilin should master the new opportunity, accelerate its agricultural development and agricultural product export trade and create favorable conditions for further optimizing agricultural cooperation with ASEAN countries and improving actual strength of agricultural production.

\section{Acknowledgments}

This paper is a scientific research initiation fund project for doctors in Jilin Engineering Normal University, No. B2016021.

\section{References}

[1] Wang Xu. Study on International Entrepreneurial Strategies of Agricultural Enterprises in Jilin. Jilin University, 2010.27-30.

[2] Xie Wanying. Study on Agricultural Product Trade Issues of Jilin. Jilin University of Finance and Economics, 2010.30-45.

[3] Bi Binbin. Study on Agricultural Product Trade Issues under CAFTA Framework. Harbin University of Commerce, 2015.34-37. 